\title{
Forest stand productivity derived from site conditions: an assessment of old Douglas-fir stands (Pseudotsuga menziesii (Mirb.) Franco var. menziesii) in Central Europe
}

\author{
Tamara Eckhart $^{1,2} \cdot$ Elisabeth Pötzelsberger ${ }^{1} \cdot$ Roland Koeck $^{1} \cdot$ Dominik Thom $^{1,3} \cdot$ Georg J. Lair $^{4} \cdot$ Marcela van Loo $^{5}$. \\ Hubert Hasenauer ${ }^{1}$
}

Received: 1 October 2018 / Accepted: 25 January 2019 / Published online: 20 February 2019

(C) The Author(s) 2019

\begin{abstract}
- Key message Douglas-fir growth correlates with the climate, the soil moisture regime, and the soil nutrient status, reflecting a broad physiological amplitude. Even though planting this non-native tree species is suggested as a viable strategy to improve adaptiveness of European forests to a more extreme climate and to assure future productivity, the expected temperature increase may induce a decline in forest stand productivity for Douglas-fir in already warm and dry regions. - Context Tree species selection is one of the most important forest management decisions to enhance forest productivity and stand stability on a given site. Douglas-fir (Pseudotsuga menziesii (Mirb.) Franco var. menziesii), a non-native species from north-western America, is seen as an important additional species option for adapting Central European forests to a changing climate.

- Aims This study assesses Douglas-fir forest productivity derived from site conditions. We investigate climatic and physicochemical soil characteristics and productivity of 28 mature Douglas-fir stands growing on siliceous, as well as carbonate bedrock material in southern Germany and north-eastern Austria.

- Methods The importance of climatic and physico-chemical soil characteristics was analyzed with the machine learning method Random Forests.

- Results The results show that Douglas-fir growth correlates with climate, soil moisture, and soil nutrient availability derived from ten climatic and physico-chemical soil parameters.
\end{abstract}

\section{Handling Editor: John M. Lhotka}

Contributions of the co-authors TE co-designed the study, collected and analyzed the data and led the writing of the manuscript. EP codesigned the study, contributed to the data collection, analysis, and writing, and verified the whole manuscript. RK collected the data, helped with the interpretation, and verified parts of the manuscript. DT analyzed the data and contributed to the writing. GJL provided advice for the soil laboratory analysis and verified parts of the manuscript. MVL helped in designing the study. HH designed the study and verified the whole manuscript.

Electronic supplementary material The online version of this article (https://doi.org/10.1007/s13595-019-0805-3) contains supplementary material, which is available to authorized users.

Elisabeth Pötzelsberger

elisabeth.poetzelsberger@boku.ac.at

1 Institute of Silviculture, University of Natural Resources and Life Sciences, 1190 Vienna, Austria

2 alpS GmbH, 6020 Innsbruck, Austria
3 Rubenstein School of Environment and Natural Resources, Burlington, VT 05405, USA

4 Institute of Soil Research, University of Natural Resources and Life Sciences, 1190 Vienna, Austria

5 Department of Botany and Biodiversity Research, University of Vienna, 1030 Vienna, Austria 
- Conclusion The broad pH optimum between 4.5 and 7.2 reflects the broad physiological amplitude of Douglas-fir, and no significant differences were detectable between carbonate and siliceous bedrock. We also conclude that climate change may induce a forest stand productivity decline, because lower productivity with the highest mean summer temperature across our study range was observed at the warmest sites in Eastern Austria.

Keywords Non-native tree species $\cdot$ Climate change adaptation $\cdot$ Site conditions $\cdot$ Site index

\section{Introduction}

Douglas-fir (Pseudotsuga menziesii (Mirb.) Franco) is a native tree species in western North America, which was introduced to Europe almost 200 years ago (Bastien et al. 2013). Currently, Douglas-fir covers more than 800,000 ha of which 50\% are in France, 25\% in Germany, and the remaining 25\% are distributed across other European countries. In Germany and Austria, $2 \%$ and $0.2 \%$, respectively, of the total forest area within the country are covered with Douglas-fir (Englisch 2008; Kownatzki et al. 2011). In its native range, Douglasfir covers an area from British Columbia (Canada) to Mexico $(2200 \times 4500 \mathrm{~km})$. The species has adapted to different ecological conditions, resulting in different growth patterns and varying phenological traits (Gould et al. 2012; Lavender and Hermann 2014). Two distinct varieties of Douglas-fir are known: (i) the coastal variety (P. menziesii var. menziesii) and (ii) the interior variety ( $P$. menziesii var. glauca) (Eckenwalder 2009). Its excellent growth performance across a wide range of site conditions, the high wood quality, and its resistance towards diseases and insects have made the species one of the most important commercial tree species in the world (Bastien et al. 2013). Based on the growth performance, provenances recommended for Central Europe come from the Cascades in Washington and Oregon (Kleinschmit and Bastien 1992; Weißenbacher 2008; Bastien et al. 2013). The interior variety is generally not recommended for Central Europe due to lower growth rates and a higher susceptibility to Swiss needle cast (Boyle 1999; Bastien et al. 2013) and therefore is not very common in this region (Hintsteiner et al. 2018). Pseudotsuga menziesii var. menziesii is however widely regarded as an especially promising option to increase productivity and to adapt European forests to climate change (Spiecker et al. 2019). With the increasing promotion of Douglas-fir, also concerns about potential negative ecological impacts are expressed from nature conservation side. Studies of ecological consequences of Douglas-fir cultivation in Europe were reviewed by Schmid et al. (2014). This review concludes that in Europe, Douglas-fir regenerates naturally especially on poor sites (dry, acidic), where it is not outcompeted by native tree species, but the ecological impacts of Douglas-fir seem to be minor compared to other non-native trees (e.g., Robinia pseudoacacia L. in Europe). Nevertheless, Douglas-fir can cause changes in species composition.
Within its natural distribution range, Douglas-fir grows on a wide range of soils and different parent materials, including marine sandstones and shales in the coastal region of northern California, Oregon, and Washington as well as soils of glacial origin in southwestern British Columbia. The soils of the northern range of the Cascades are derived from metamorphosed sedimentary material, while igneous rocks and formations of volcanic origin are important in the southern Cascades. The highest growth rates are reported on well-aerated soils with a $\mathrm{pH}$ value ranging from 5 to 6 . Poorly drained or compacted soils inhibit Douglas-fir growth (Lavender and Hermann 2014). Climatic variation in the natural range is large. The coastal variety in the Pacific Northwest experiences a maritime climate with mean annual precipitation rates of 760 $3000 \mathrm{~mm}$, and a more continental climate towards the east of the Cascades (annual precipitation 600-3000 $\mathrm{mm}$ ) (Lavender and Hermann 2014). Compared to the climate in Central Europe, most of the precipitation occurs in winter (Englisch 2008), and the summer period is relatively dry.

In Central Europe, Douglas-fir has mainly been introduced on well-drained, aerated, and carbonate-free soils. Since the beginning of Douglas-fir management in Europe, a lot of attention has been given to the carbonate content, as Douglas-fir growing on calcareous soils often shows leaf yellowing (chlorosis) (Englisch 2008). Furthermore, on sites with high manganese concentration, symptoms of toxicity have been reported (LWF 2008). However, little information is available on the growth performance across different soil types in Europe. This lack of knowledge is problematic, as for an active forest transformation, where tree species sensitive to climate change are replaced by better adapted native or non-native trees (Bolte et al. 2010), Douglas-fir is seen as one of the most promising options and is therefore more and more planted by forest owners. Consequently, with the increasing interest in planting Douglas-fir, there is also higher interest of forest owners in better understanding the site-suitability of Douglas-fir to avoid costly cultivation failures. In the case of this non-native tree species, which has been first introduced to Europe in 1827, a limited number of mature stands still exist. These stands can be analyzed in retrospect to determine the site impact on the productivity potential. In this paper, we investigate a wide range of physico-chemical soil and climatic characteristics to assess the productivity of 28 mature Douglas-fir stands growing on soils developed on siliceous and carbonate bedrock in southern 
Germany and north-eastern Austria. We are interested in deriving the forest stand productivity across different site conditions by assessing the importance of specific climatic and physicochemical soil characteristics for the recorded growth performance of even-aged mature Douglas-fir stands. As a proxy of forest stand productivity, the site index at the age of 60 years was used. Because of the strong interdependency of impacts of climate and soil on forest growth, the aim was to derive the effect sizes and independent effects of climate and soil parameters on the site index with an advanced statistical method, the Random Forests regression approach. The objectives of this study were (i) to determine the dominant climatic and physico-chemical soil parameters and (ii) to show their effect size and correlation with the forest stand productivity of Douglas-fir in Central Europe.

\section{Material and methods}

\subsection{Study sites}

In 28 even-aged Douglas-fir stands with (i) stand age 40120 years, (ii) stand size $\geq 1$ ha, and (iii) proportion of Douglas-fir basal area $\geq 80 \%$, tree data, physico-chemical soil data, and climatic data were collected. The forest stands are located over a 600-km-long and 150-km-wide band north-east of the Alps, stretching across three Austrian provinces
(Burgenland, Lower Austria, Upper Austria) and two German provinces (Baden-Württemberg, Bavaria) (see Fig. 1). With these forest stands, we cover a wide range of site, climatic, geological, and topographic variation in Central Europe (Table 1).

In the drier areas of Eastern Austria (Burgenland, parts of Lower Austria), annual precipitation ranges from 570 to $790 \mathrm{~mm}$, and the mean annual temperature ranges between 8.9 and $9.9{ }^{\circ} \mathrm{C}$. In Southern Germany and along the northern border of the Austrian Alps, the conditions are more humid with an annual precipitation between 810 and $2100 \mathrm{~mm}$ and a mean annual temperature between 7.0 and $9.1{ }^{\circ} \mathrm{C}$.

All selected forest stands originate from the coastal and western Cascade region of Oregon and Washington. The native origin of the Douglas-fir stands was analyzed in a recent study by Hintsteiner et al. (2018) and/or was confirmed by the forest owners. Hintsteiner et al. (2018) assigned 26 out of 28 study sites to only one genetic cluster, cluster I, and two sites to the directly adjacent genetic cluster II (Fig. S1). These genetic clusters (cluster I and cluster II) comprise the most important Douglas-fir provenances, which are recommended for the study area in Germany and Austria and for which a similar growth performance in provenance trials has been determined (Kleinschmit et al. 1979; Ruetz 1981; Schultze and Raschka 2002; Chakraborty et al. 2016). Hence, we were

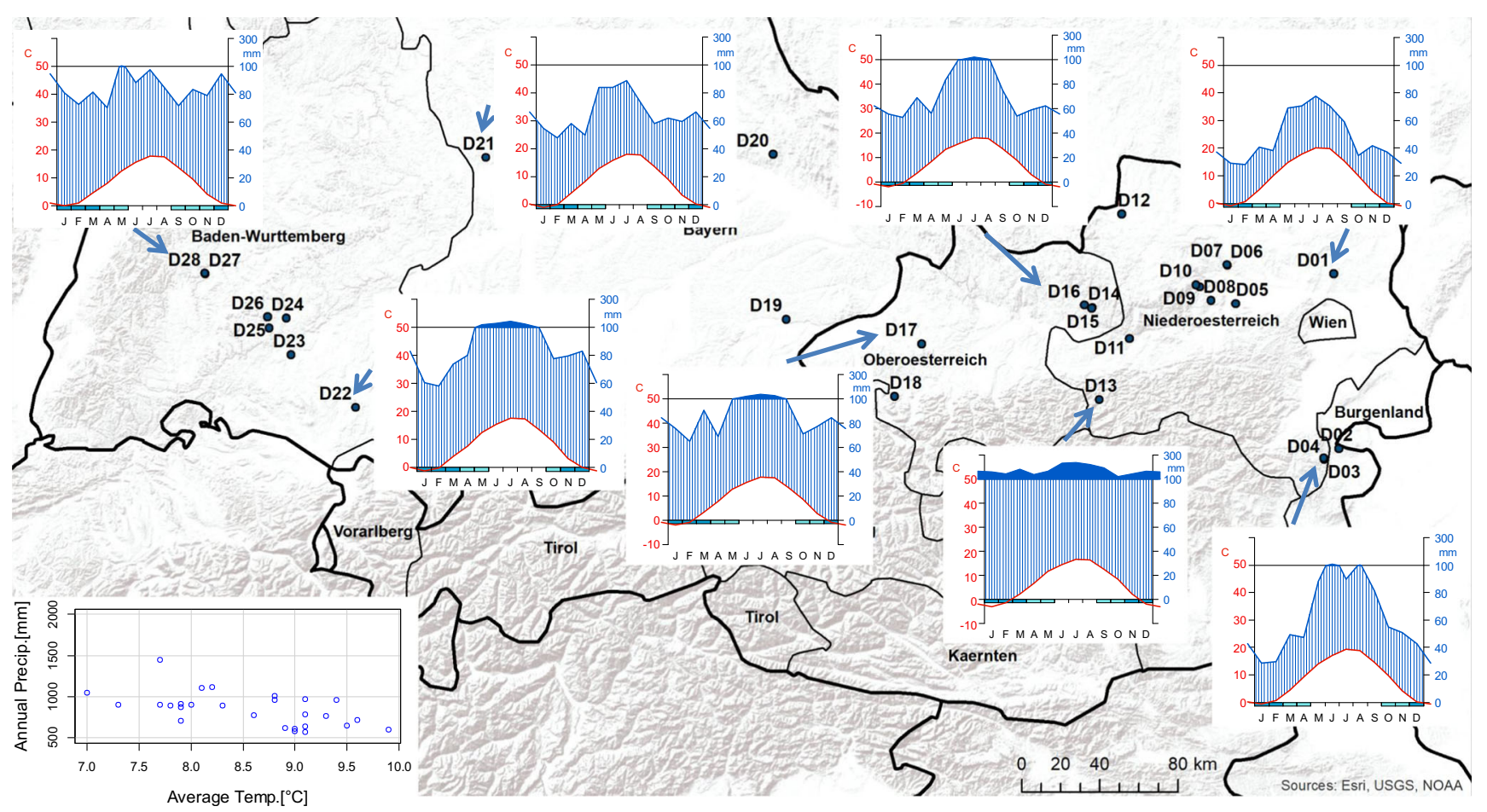

Fig. 1 Location of all 28 Douglas-fir sites, climatic region (mean annual temperature and mean annual precipitation), and selected climate diagrams which are representative for the different regions for the years 1981-2010 
Table 1 Investigated Douglas-fir stands (D01-D28): site index (SI height at the age of 60 years), annual precipitation (Annual Precip.), mean annual temperature (Annual Temp.), elevation in meters above sea level and geology

\begin{tabular}{|c|c|c|c|c|c|}
\hline Site & $\begin{array}{l}\text { SI } \\
(\mathrm{m})\end{array}$ & $\begin{array}{l}\text { Annual Precip. } \\
(\mathrm{mm})\end{array}$ & $\begin{array}{l}\text { Annual Temp. } \\
\left({ }^{\circ} \mathrm{C}\right)\end{array}$ & $\begin{array}{l}\text { Elevation } \\
{[\mathrm{m}]}\end{array}$ & Geology \\
\hline D01 & 28.2 & 600 & 9.9 & 290 & Loess \\
\hline D02 & 36 & 720 & 9.6 & 460 & Boulders in a sand-loam matrix \\
\hline D03 & 36.9 & 790 & 9.1 & 560 & Mica schist, quartz phyllonite \\
\hline D04 & 31.1 & 770 & 9.3 & 520 & Muscovite gneiss \\
\hline D05 & 34.4 & 650 & 9.5 & 360 & Sand and argillaceous marl \\
\hline D06 & 29.6 & 570 & 9.1 & 370 & Granulite \\
\hline D07 & 25.3 & 580 & 9 & 400 & Granulite \\
\hline D08 & 34 & 640 & 9.1 & 430 & Granulite \\
\hline D09 & 39 & 620 & 8.9 & 440 & Migmatized granite-gneiss \\
\hline D10 & 36.6 & 610 & 9 & 410 & $\begin{array}{l}\text { Paragneiss, locally mica schist } \\
\text { (partly migmatized) }\end{array}$ \\
\hline D11 & 36 & 960 & 9.4 & 330 & Rubble \\
\hline D12 & 30.3 & 710 & 7.9 & 530 & Granite \\
\hline D13 & 41.7 & 2100 & 7.1 & 820 & $\begin{array}{l}\text { Carbonate-free, fine sandstone, } \\
\text { arkose, slate, stone coal }\end{array}$ \\
\hline D14 & 39.7 & 900 & 8 & 640 & Granite \\
\hline D15 & 41.6 & 910 & 7.9 & 660 & Granite \\
\hline D16 & 39.9 & 890 & 8.3 & 590 & Granite \\
\hline D17 & 34.8 & 1111 & 8.1 & 660 & Gravel in sand matrix, fluvial \\
\hline D18 & 34.6 & 1450 & 7.7 & 810 & Sandstone, calcareous marl \\
\hline D19 & 38.9 & 960 & 8.8 & 480 & Silt, clayey-sandy, often gravelly \\
\hline D20 & 34 & 900 & 7.3 & 680 & Biotite-granite \\
\hline $\mathrm{D} 21$ & 37.5 & 780 & 8.6 & 480 & Impact breccia \\
\hline D22 & 38.5 & 1120 & 8.2 & 670 & Glacial till, silt, sand, gravel and stones \\
\hline D23 & 42.1 & 870 & 7.9 & 660 & Gravel, silt, clay, often stones, rubble \\
\hline D24 & 30.7 & 900 & 7.7 & 700 & Limestone, dolomite \\
\hline D25 & 31.1 & 890 & 7.8 & 700 & Sponge-stromatolite-corallian limestone \\
\hline D26 & 36.7 & 1050 & 7 & 890 & Limestone, dolomite \\
\hline D27 & 37.3 & 970 & 9.1 & 450 & Limestone, dolomite \\
\hline D28 & 35.4 & 1010 & 8.8 & 520 & Dolomite \\
\hline
\end{tabular}

able to minimize any potential genetic differences in the growth performances, and the bias genetic differences may have induced in assessing the forest stand productivity.

\subsection{Forest data}

In each of the 28 Douglas-fir stands, individual tree data were collected based on four angle-count sampling plots with a basal area factor of 4 (see Bitterlich 1948). For each tree, we recorded the diameter at breast height (dbh), height, age, position, and tree species. The dominant tree height by species of the angle-count sample plots was calculated as the mean height of the three trees with the largest dbh (Pollanschütz 1971). Stand age was determined by coring and counting the year-rings of the mean diameter tree of the angle-count sample.
The site index (SI) for all 28 Douglas-fir stands was defined as the mean dominant tree height at age 60 years (Kindermann and Hasenauer 2005). This site index at 60 years (SI60) was iteratively calculated according to the dominant height growth function after Mitscherlich/Richard (1919) for "Douglas-fir north-western Germany DoNwd" (Kindermann and Hasenauer 2005):

$\mathrm{SI}=a\left(1-e^{-b^{*} t}\right)^{c}$

$a=a_{0}+a_{1} * S I_{60}+a_{2} * S I 2_{60}$

$b=b_{0}+b_{1} * S I_{60}+b_{2} * S I 2_{60}$

$c=c_{0}+c_{1} * S I_{60}+c_{2} * S I 2_{60}$

where, SI is the mean dominant tree height, SI60 is the dominant tree height at the age of 60 years, $t$ the stand age, and $a, b$, and $c$ the coefficients for "Douglas-fir north-western Germany (DoNwd)" based on the yield table from Bergel (1985) (see Table S1). 


\subsection{Climate data}

Site-specific climate information for the years 1981 to 2010 was derived with the climate interpolation tool DAYMET, which had been validated and adapted for Austria, using the national climate station network (several hundreds of stations) from Austria and Germany (Thornton et al. 2000; Petritsch 2002; Hasenauer et al. 2003). With DAYMET, daily minimum and maximum temperature (Tmin, Tmax) and precipitation (Prcp) were interpolated to each site from surrounding, 25 (temperature) and 15 (precipitation) climate stations, respectively, and daily mean temperature (Tmean) was calculated as the mean of Tmin and Tmax (Table 1). For more details on the interpolation routine, see Petritsch and Hasenauer (2014).

\subsection{Soil sampling and properties}

Humus layers and mineral soil horizons were determined according to the "Guidelines for Forest Site Mapping in Austria" (Englisch and Kilian 1999) for each of our 28 Douglas-fir stands. Mineral soil samples were extracted with a Pürckhauer type gauge auger. Diagnostic soil horizons were separated and described according to depth, horizon boundaries, texture, rock content, color, concretions, carbonate presence, structure, rooting intensity, and earthworm activity.

At each plot, 11 sub-samples in 1-m distance along a diagonal transect were collected to a depth of $35 \mathrm{~cm}$ with a gauge auger. The 11 soil samples were separated into layer A (A horizon) and B (mineral soil), mixed and homogenized in a bucket before further use. At each stand, four separate soil profiles, each derived from 11 sub-samples, were analyzed. The bulk density for layers A and B was measured in undisturbed soil samples taken with metal cylinders (volume $100 \mathrm{~cm}^{3}$ ). The composite (mixed) samples were air-dried and sieved to $2 \mathrm{~mm}$. We used the weight of the macroscopic organic material (including roots) and rocks to calculate the coarse fragment content in the air-dried soil sample.

Soil acidity ( $\mathrm{pH}$ value) was determined in a $\mathrm{H}_{2} \mathrm{O}$ saturation extract with a soil-to-solution ratio of 1:2.5 as described in the Austrian standard ÖNORM L 1083 (1989). Total carbon of the bulk soils was measured after dry combustion as described in ÖNORM L 1080 (1999). The carbonate content of the soil samples was measured by the Scheibler method (see ÖNORM L 1084, 1989) to calculate the content of inorganic C. Organic carbon was then calculated as the difference of total and carbonate carbon. The determination of total nitrogen $(\mathrm{N})$ was carried out with the method after Kjieldahl as described in the Austrian standard ÖNORM L 1082 (2009), and the carbon to nitrogen ratio $(\mathrm{C} / \mathrm{N})$ is the organic carbon content divided by the total nitrogen content. The exchangeable cations $(\mathrm{Ca}, \mathrm{Mg}, \mathrm{K}, \mathrm{Na}$, $\mathrm{Al}, \mathrm{Fe}, \mathrm{Mn}, \mathrm{H}$ ) were measured according to the Austrian standard ÖNORM L 1086 (2001), extracting $5 \mathrm{~g}$ of soil with $100 \mathrm{ml}$ $0.1 \mathrm{M} \mathrm{BaCl}_{2}$ solution. Effective cation-exchange capacity
(CEC eff.) and base saturation (BS) were calculated as the sum of the exchangeable cations and the percentage of the CEC occupied by the basic cations $\mathrm{K}, \mathrm{Na}, \mathrm{Ca}$, and $\mathrm{Mg}$. The anion nutrients nitrate $\left(\mathrm{NO}_{3}{ }^{-}\right)$, nitrite $\left(\mathrm{NO}_{2}{ }^{-}\right)$, phosphate $\left(\mathrm{PO}_{4}{ }^{3-}\right)$, and sulfate $\left(\mathrm{SO}_{4}{ }^{2-}\right)$ were determined in a $\mathrm{H}_{2} \mathrm{O}$ saturation extract as described in ÖNORM L 1092 (2005), extracting $5 \mathrm{~g}$ of soil with $50 \mathrm{ml} \mathrm{H}_{2} \mathrm{O}$ solution. The water extraction determines the anion nutrients in the soil solution, thus dissolved of readily soluble forms. The soil particle size distribution was determined by use of wet-sieving and sedimentation with the pipette analysis (Köhn pipette) after adding $\mathrm{H}_{2} \mathrm{O}_{2}$ to remove organic matter and dispersing with $50 \mathrm{ml}$ sodium pyrophosphate (ÖNORM L 1061, 2002). For each soil parameter, we calculated the arithmetic mean of the four samples per layer, collected in one stand. The cation and anion nutrients, total nitrogen, and carbon were expressed as soil stocks on a mass per unit area basis using bulk density, coarse fragment content, and depth of layers A and B $(0-35 \mathrm{~cm})$. Pore volume (PV) was calculated using bulk density and a particle density following Osman (2013). The water holding capacity at field capacity, defined as $-0.015 \mathrm{MPa}$, was calculated based on soil depth and sand, silt, and clay percentages using empirical pedo-transfer functions of Clapp and Hornberger (1978) and Cosby et al. (1984) (Table S1, Eqs. 1-5).

\subsection{Geology data}

The investigated Douglas-fir stands grow on soils developed on siliceous (D01-D23) and carbonate bedrock (D24-D28) (see Table 1). The exact geology for the Austrian stands was extracted from geological maps of the Geological Survey of Austria (GBA), if available 1:50,000 otherwise 1:200,000 maps for Upper Austria (Oberösterreich) and Lower Austria (Niederösterreich). The geology for the German stands was extracted from 1:200,000 geological maps of the German Federal Institute for Geosciences and Natural Resources (BGR).

\subsection{Statistical analysis of Douglas-fir productivity versus site parameters}

The site index defined as the mean dominant tree height at age 60 is used as a measure for forest stand productivity. Thus, we correlate the site index (Table 2) to a set of 25 climatic and physico-chemical soil parameters determined for each of the 28 Douglas-fir stands (D01-D28-see Table 2). We used the statistical method Random Forests (Breiman 2001) to select the number of predictors and derive their effect size on the site index. Random Forests fits decision trees according to hierarchical levels. Subsequently, all individual trees (weak learners) are aggregated to a random forest (strong learner) using the bootstrap approach, where about $63 \%$ of the original observations are used for the prediction and the remaining $37 \%$ are "out-of-bag" observations that determine the 
Table 2 Summary of the dependent variable and the 25 candidate variables of the 28 Douglas-fir stands for statistical analysis with Random Forests. Climate variables refer to the summer months June, July and August. Soil variables are the depth-weighted mean values of layers A and B. Geology relate to calcareous site or silicate site

\begin{tabular}{|c|c|c|c|c|c|c|}
\hline Variable group & Acronym & Description & Unit & Mean & Min & Max \\
\hline Site index & SI & $\begin{array}{l}\text { Mean dominant tree height } \\
\text { at age } 60 \text { years }\end{array}$ & $\mathrm{m}$ & 35.4 & 25.3 & 42.1 \\
\hline \multirow[t]{2}{*}{ Climate } & Tmean & $\begin{array}{l}\text { Mean summer temperature } \\
\text { [JJA] }\end{array}$ & ${ }^{\circ} \mathrm{C}$ & 17.4 & 15.8 & 19.3 \\
\hline & Psum & Summer precipitation [JJA] & $\mathrm{mm}$ & 313 & 219 & 690 \\
\hline \multirow[t]{22}{*}{ Soil } & $\mathrm{pH} \mathrm{H} \mathrm{H}_{2} \mathrm{O}$ & Actual $\mathrm{pH}$ & {$[-]$} & 5.0 & 4.0 & 7.8 \\
\hline & $\mathrm{C}$ & Carbon & $\mathrm{t} / \mathrm{ha}$ & 43 & 14 & 119 \\
\hline & $\mathrm{N}$ & Nitrogen & t/ha & 3 & 0.5 & 9 \\
\hline & $\mathrm{C} / \mathrm{N}$ & $\mathrm{C} / \mathrm{N}$ ratio & {$[-]$} & 18 & 11 & 30 \\
\hline & $\mathrm{Ca}$ & Calcium & $\mathrm{kg} / \mathrm{ha}$ & 3929 & 23 & 25,298 \\
\hline & $\mathrm{Mg}$ & Magnesium & $\mathrm{kg} / \mathrm{ha}$ & 312 & 3 & 2508 \\
\hline & $\mathrm{K}$ & Potassium & $\mathrm{kg} / \mathrm{ha}$ & 108 & 22 & 250 \\
\hline & $\mathrm{Fe}$ & Iron & $\mathrm{kg} / \mathrm{ha}$ & 18 & 0 & 76 \\
\hline & $\mathrm{Al}$ & Aluminum & $\mathrm{kg} / \mathrm{ha}$ & 592 & 0 & 1859 \\
\hline & $\mathrm{Mn}$ & Manganese & $\mathrm{kg} / \mathrm{ha}$ & 72 & 0.1 & 275 \\
\hline & CEC eff. & Cation-exchange capacity & $\mathrm{mmol} / \mathrm{kg}$ & 157 & 40 & 657 \\
\hline & Bsat & Base saturation & $\%$ & 47 & 10 & 100 \\
\hline & $\mathrm{NO}_{3}^{-}$ & Nitrate & $\mathrm{kg} / \mathrm{ha}$ & 13 & 0.4 & 58 \\
\hline & $\mathrm{NO}_{2}^{-}$ & Nitrite & $\mathrm{kg} / \mathrm{ha}$ & 1 & 0 & 6 \\
\hline & $\mathrm{PO}_{4}{ }^{3-}$ & Phosphate & $\mathrm{kg} / \mathrm{ha}$ & 1 & 0 & 10 \\
\hline & $\mathrm{SO}_{4}{ }^{2-}$ & Sulfate & $\mathrm{kg} / \mathrm{ha}$ & 13 & 1 & 69 \\
\hline & Clay & Clay & $\%$ & 19 & 6 & 47 \\
\hline & Sand & Sand & $\%$ & 36 & 0 & 60 \\
\hline & Skeleton & Soil skeleton & $\%$ & 14 & 1 & 40 \\
\hline & PV & Pore volume & $\%$ & 69 & 50 & 84 \\
\hline & Soil depth & Effective soil depth & $\mathrm{cm}$ & 82 & 33 & 149 \\
\hline & WHC & Water holding capacity & $\mathrm{mm}$ & 275 & 128 & 565 \\
\hline $\begin{array}{l}\text { Discrete variable } \\
\text { group }\end{array}$ & \multicolumn{2}{|l|}{ Description } & Unit & \multicolumn{3}{|c|}{ Allocation } \\
\hline Geology & \multicolumn{2}{|c|}{ Carbonate or siliceous bedrock } & Dummy $(1 / 0)$ & \multicolumn{3}{|c|}{5 sites $(1), 23$ sites $(0)$} \\
\hline
\end{tabular}

accuracy and error rates of the predictions (e.g., cross-validation). In contrast to many other statistical methods (e.g., AIC and BIC), Random Forests measures the importance of a variable directly using the misclassification rate of the out-of-bag observations (Cutler et al. 2007).

Random Forests was used since it (i) is a non-parametric method, which is able to illustrate saturation levels as well as optimum ranges of key site factors driving Douglas-fir growth, (ii) has a high prediction accuracy even if predictor variables are moderately collinear (Dormann et al. 2013), and (iii) can deal with different variable types. The statistical analysis was carried out in two main steps.

I. Variable pre-selection: First, we eliminated irrelevant predictors using the Random Forests-based variable selection procedure of the VSURF package in R (Genuer et al. 2015) and optimized the number of variables randomly sampled as candidates for each tree using the tune RF function of the Random Forests package (Liaw and Wiener 2015). This function uses different numbers of candidate variables to fit the regression trees. The model with the lowest out-of-bag error indicates the best estimate.

II. Building the final Random Forests model: We fitted the Random Forests model using 2000 regression trees. We used the mean square error (MSE) as a measure of variable importance, which indicates the decrease in model accuracy by randomly permuting the observations of a variable. Partial dependence plots illustrate the marginal effect of each explanatory variable on site index variation while averaging other variable effects (Cutler et al. 2007).

\section{Results}

Site index as the dominant height at age 60 years (Table 1) ranged between $25.3 \mathrm{~m}$ (D07) and $42.1 \mathrm{~m}$ (D23). For the analysis with Random Forests, we used 25 potential 
explanatory variables (Table 2) from 28 observations to explain the variation in site index. From the 25 candidate variables, forward selection procedure resulted in ten variables which were further analyzed with Random Forests. These ten variables contained soil and climatic parameters and explained $30.3 \%$ of the variance (pseudo $R^{2}=0.303$ ). Variable importance rankings revealed that summer precipitation exhibited the largest impact in explaining site index variation (Fig. 2). Next, phosphate $\left(\mathrm{PO}_{4}{ }^{3-}\right)$ and water holding capacity (WHC) were found to be important, followed by sulfate $\left(\mathrm{SO}_{4}{ }^{2-}\right)$, summer mean temperature, iron $\left(\mathrm{Fe}^{3+}\right)$, sand content, nitrate $\left(\mathrm{NO}_{3}{ }^{-}\right)$, clay content, and $\mathrm{pH}$ value. Partial effect plots indicated a non-linear relationship between site index and the ten explanatory variables (see Fig. 3).

Summer precipitation and water holding capacity were positively correlated with the site index. Both impacted distinctively Douglas-fir growth if values dropped below $270 \mathrm{~mm}$ and $300 \mathrm{~mm}$, respectively. Higher summer precipitation and water holding capacity values did not lead to a further improvement in site index and thus in productivity of Douglas-fir stands. The partial dependence plots also indicated that nutrient requirements of phosphate $\left(\mathrm{PO}_{4}{ }^{3-}\right)$, sulfate $\left(\mathrm{SO}_{4}{ }^{2-}\right)$, and nitrate $\left(\mathrm{NO}_{3}{ }^{-}\right)$begin to saturate at stock rates of $0.2 \mathrm{~kg} / \mathrm{ha}, 20 \mathrm{~kg} / \mathrm{ha}$, and $10 \mathrm{~kg} / \mathrm{ha}$, respectively. Iron $\left(\mathrm{Fe}^{3+}\right)$ stocks above $18 \mathrm{~kg} / \mathrm{ha}$ showed a negative sigmoidal relationship with the site index. The impact of mean summer temperature on the site index was optimal between 17 and $18^{\circ} \mathrm{C}$ and decreased above $18{ }^{\circ} \mathrm{C}$.

Site index dropped if the sand content exceeded $45 \%$. The clay content showed an optimal range between $18 \%$ and $26 \%$, whereas the site index decreased with clay contents greater than $38 \%$. The $\mathrm{pH}$ value showed a broad optimum between

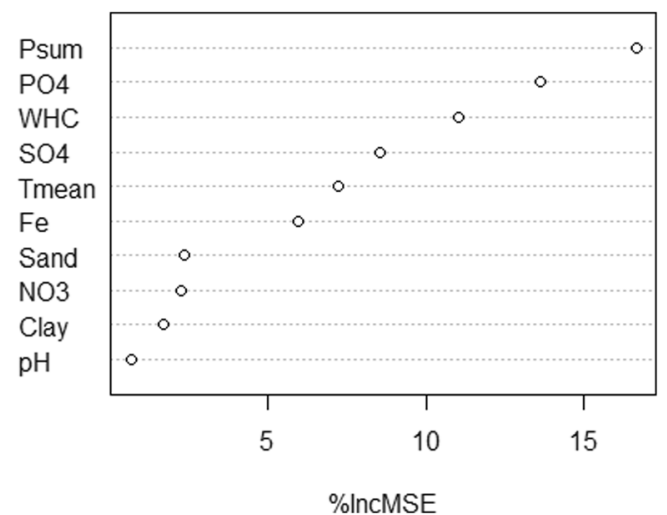

Fig. 2 Variable importance plot (all other variables were not meaningful), where the variable importance is expressed as the percentage increase in mean square error (\%IncMSE). The mean square error (MSE) indicates the loss of predictive power of the same model by omitting a variable. Variable elimination using VSURF (step 1: preliminary elimination and ranking). The variables summer precipitation (Psum, mm), phosphate (PO4, kg/ha), water holding capacity (WHC, mm), sulfate (SO4, kg/ ha), mean summer temperature (Tmean, $\left.{ }^{\circ} \mathrm{C}\right)$, iron $(\mathrm{Fe}, \mathrm{kg} / \mathrm{ha})$, sand content $(\%)$, nitrate $(\mathrm{NO} 3, \mathrm{~kg} / \mathrm{ha})$, clay content $(\%)$, and $\mathrm{pH}$ value explain $30.3 \%$ of the variance (pseudo $R^{2}=0.303$ )
4.5 and 7.2. The 3D plot (Fig. 4) illustrates the joint impact of climate variables, summer precipitation, and mean summer temperature. The temperature optimum is independent from the amount of precipitation (Fig. 4). High summer precipitation does not avoid a drop in the site index if mean summer temperatures exceed $18{ }^{\circ} \mathrm{C}$. A decline in site index by $3-4$ classes is evident, if the summer precipitation drops below $300 \mathrm{~mm}$.

\section{Discussion}

Studying the relationship between forest stand productivity and site characteristics has a long tradition in forest science (Aertsen et al. 2010). Many of the early studies used basic statistical methods like linear regression for the analysis (e.g., Carter and Klinka 1990, Curt et al. 2001, Fontes et al. 2010), which do not account for potential non-linearities in ecological relations and show problems with collinearity (Aertsen et al. 2010). The Random Forests approach, compared to traditional statistical methods can be classified as less transparent ("black box" model). It is able to identify structures in complex, often non-linear data sets (Olden et al. 2008) and is resilient to collinearity (Dormann et al. 2013). In our analysis, Random Forests identified ten of our 25 investigated climatic and physico-chemical soil parameters that drive Douglas-fir productivity (see Fig. 2) in Central Europe, and assessed a non-linear relationship between the predictors and the response (Fig. 3). The summer precipitation (Psum) and water holding capacity (WHC) (Fig. 2) are two of the three most important site characteristics and directly refer to the water budget. The third of the three important variables is phosphate $\left(\mathrm{PO}_{4}{ }^{3-}\right)$, a common cause for forest productivity limitation, which is often neglected in site-growth studies (Bontemps and Bouriaud 2014).

Our results suggest that a low summer precipitation (< $270 \mathrm{~mm})$ and a low water holding capacity $(<300 \mathrm{~mm})$ reduce productivity (see Fig. 3). This confirms the findings by Carter and Klinka (1990) as well as Curt et al. (2001), who showed a significant correlation between Douglas-fir site index versus soil water-deficit and available soil water storage, respectively. The optimal soil water conditions for Douglas-fir can be expressed by the available water storage capacity (AWSC). The AWSC describes the portion of soil water which is accessible to plant roots, i.e., water in medium-sized pores. It can be estimated from the water holding capacity (WHC) and the soil type (Blume et al. 2010). On silty soils, a proportion of $15 \%$ for medium pores (Blume et al. 2010) can be assumed. According to the detected optimal WHC of $>300 \mathrm{~mm}$, the estimated AWSC is about $45 \mathrm{~mm}$ and can be classified as "low" for Douglas-fir (Leitgeb et al. 2012).

Douglas-fir productivity declines if the mean summer temperature (Tmean) exceeds $18{ }^{\circ} \mathrm{C}$ (Fig. 3). This temperature 
Fig. 3 Partial effect plots based on results from the Random Forests analysis, showing the mean marginal influence of ten explanatory variables summer precipitation (Psum), phosphate (PO4), water holding capacity (WHC), sulfate (SO4), mean summer temperature (Tmean), iron $(\mathrm{Fe})$, sand content, nitrate (NO3), clay content, and $\mathrm{pH}$ value on site index variation. Each plot represents the effect of the explanatory variable while holding the other variables constant
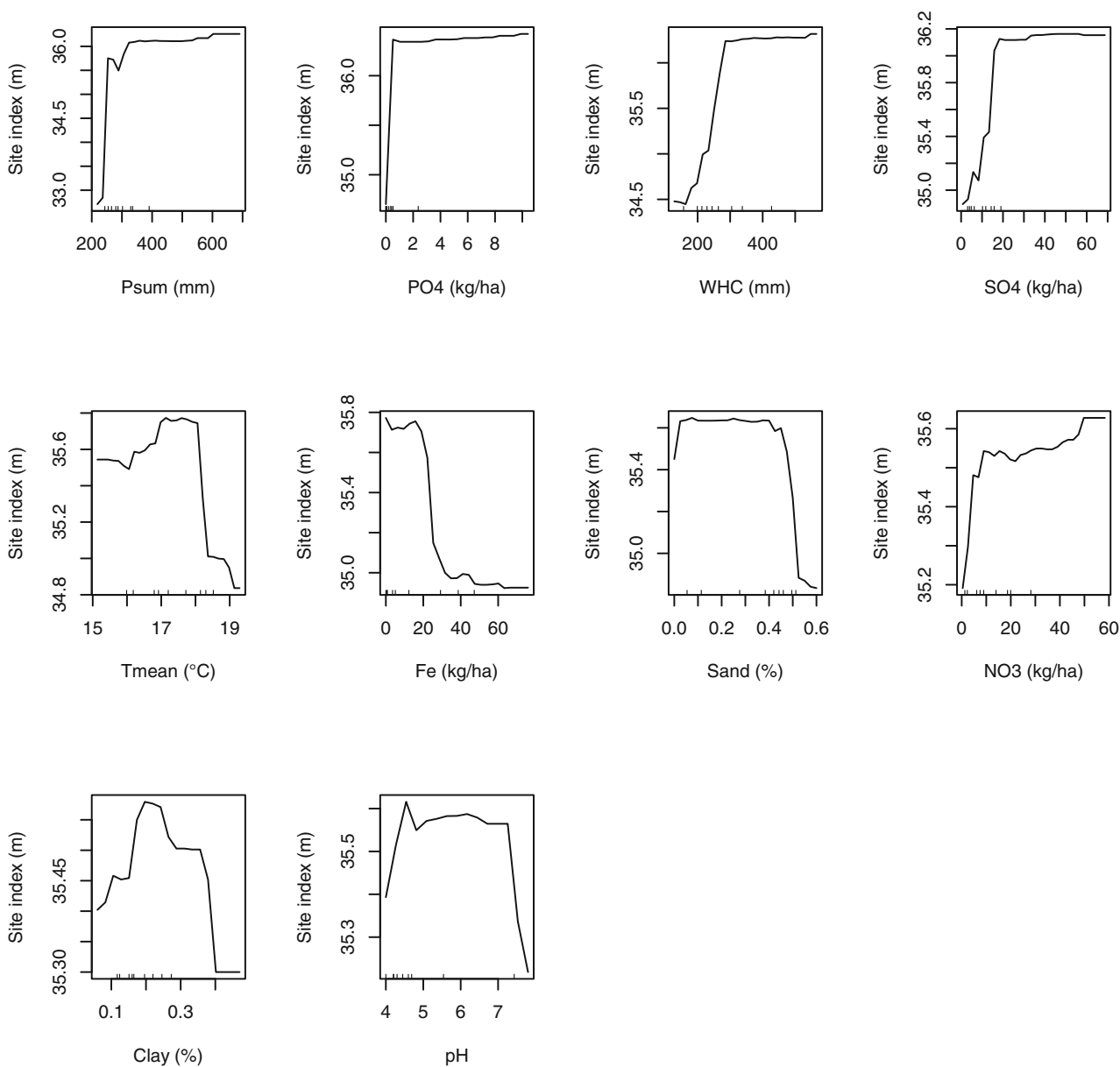

sensitivity at high temperatures might be related to an increase in vapor pressure deficit, which was shown by Restaino et al. (2016) to be strongly correlated with decreased Douglas-fir growth across forests in the Western United States. The detected moderate increase in productivity with mean summer temperatures between $15^{\circ} \mathrm{C}$ and $17^{\circ} \mathrm{C}$ (Fig. 3) supports the findings of Jansen et al. (2013), who found higher growth rates at lower elevations. These findings are important in the context of expected climate change, since global mean annual temperatures are projected to increase between $1.1{ }^{\circ} \mathrm{C}(\mathrm{RCP}$ 4.5 ) and $4.8^{\circ} \mathrm{C}$ (RCP 8.5 ) by 2100 (IPCC 2014). Accordingly, water stress may become an important limitation for productivity due to a combined effect of changes in summer temperature and summer precipitation (Fig. 4) on the warmest sites in Eastern Austria (D01-D11, mean summer temperature > $18{ }^{\circ} \mathrm{C}$ ) (Fig. 1, Table S3). Higher soil phosphate $\left(\mathrm{PO}_{4}{ }^{3-}\right)$, sulfate $\left(\mathrm{SO}_{4}{ }^{2-}\right)$, and nitrogen $\left(\mathrm{NO}_{3}{ }^{-}\right)$contents show an increase in Douglas-fir productivity (Fig. 3). Phosphorus and nitrogen are often the main limiting nutrients for plant growth (Lambers et al. 1998). Crop production studies show a link between sulfur and nitrogen, which are often co-limiting (Hawkesford and De Kok 2006; Fageria 2014). If the iron $\left(\mathrm{Fe}^{3+}\right)$ concentration exceeds $18 \mathrm{~kg} / \mathrm{ha}$, site productivity dropped (see Fig. 3). This confirms that iron plays a crucial 
role in metabolic processes, but may turn toxic if critical accumulation levels are exceeded (Rout and Sahoo 2015).

The physical soil properties sand and clay content lead to varying soil fertility and productivity. While on sandy soils (sand content $>45 \%$ ) and clayey soils (clay content $>38 \%$ ), a decline in Douglas-fir growth is evident, a moderate clay content improved productivity (see Fig. 3). Sandy soils drain more water and are poor in fertility as well as water supply (Osman 2013). Soils with clay content above 40\%, which are classified as clayey soils (Blume et al. 2010), retain large amounts of water but drain very slowly. Thus they are often waterlogged (Osman 2013), which induces damages of the fine root system of Douglas-fir (Englisch 2008; Lavender and Hermann 2014). Rout and Sahoo (2015) found that under waterlogged and acidic soil conditions, iron may be taken up excessively leading to damages of vital cellular constituents in plants.

Our study included five Douglas-fir stands growing on carbonate soils (see Table 1). Although current management recommendations in Austria and Germany suggest planting Douglas-fir on carbonate-free soils (e.g., Englisch 2008), no significant decline in productivity (e.g., site index) between our old Douglas-fir stands on carbonate soils (SI: $\mu=34.2 \mathrm{~m}$ ) versus siliceous soils (SI: $\mu=35.7 \mathrm{~m}$ ) was detectable (see Table 3). This finding was also supported by our analysis with Random Forests, where the dummy variable "carbonate" or "siliceous bedrock" (1/0) did not enter the final model (Fig. 2, Table 2). Within this context, it has to be highlighted that the forest soils of all five Douglas-fir stands on carbonate sites show high loam contents, and the results cannot be extrapolated, e.g., to Rendzina sites. The carbonate sites showed phosphorus below the detection limit (Table 3), which is typical for soils with $\mathrm{pH}$ values above 7 as phosphorus is fixed as

Table 3 Mean value and standard deviation (sd) of site index (SI) and the ten influencing site variables grouped by geology: Calc. group refer to calcareous sites ( $n$ 5) and silic. group to silicate sites $(n 23)$

\begin{tabular}{lrrrrr}
\hline & \multicolumn{2}{c}{ Calc. group } & & \multicolumn{2}{c}{ Silic. group } \\
\cline { 2 - 3 } \cline { 6 - 7 } Variables & Mean & sd & & Mean & sd \\
\hline Site index (SI) & 34.2 & 3.1 & & 35.7 & 4.5 \\
Summer precipitation (Psum) & 287.8 & 26.1 & & 319.7 & 103.8 \\
Phosphate $\left(\mathrm{PO}_{4}{ }^{3-}\right.$ ) & 0.0 & 0.0 & 1.3 & 2.8 \\
Water holding capacity (WHC) & 255.2 & 92.2 & & 280.7 & 114.2 \\
Sulfate $\left(\mathrm{SO}_{4}{ }^{2-}\right.$ ) & 2.9 & 1.3 & & 14.9 & 14.7 \\
Mean summer temperature & 16.3 & 0.9 & & 17.5 & 1.0 \\
$\quad$ (Tmean) & 0.0 & 0.0 & & 20.9 & 21.9 \\
Iron (Fe) & $4 \%$ & $3 \%$ & & $41 \%$ & $12 \%$ \\
Sand content & 17.6 & 6.5 & 12.8 & 14.5 \\
Nitrate $\left(\mathrm{NO}_{3}{ }^{-}\right.$) & $31 \%$ & $9 \%$ & & $17 \%$ & $5 \%$ \\
Clay content & 7.5 & 0.2 & & 4.4 & 0.4 \\
pH value & & & &
\end{tabular}

calcium phosphate (Rowell 1994). Phosphorus is a rather immobile element in the soil compared to other nutrients and its availability is $\mathrm{pH}$ dependent. However, plants are able to change the $\mathrm{pH}$ value in the rhizosphere by root exudation to mobilize P of calcium phosphates (George et al. 2012). Moreover, mycorrhizal associations to enhance plant $\mathrm{P}$ uptake (Lambers et al. 2006) may supply the trees especially in cases of very low readily available phosphate content. Considering these mechanisms for increasing P-availability and the potentially different relative importance of the other site parameters on carbonate sites, the measured zero value of $\mathrm{PO}_{4}{ }^{3-}$ on carbonate sites does not contradict our finding of the overall high importance of phosphate. Essentially, with the selection of our studied forest stands, we did not intend to explore the very limits of Douglas-fir growth for any specific site parameter. Our study design of investigating old Douglas-fir stands, however, revealed ecologically meaningful non-linear relations over a wide range of site qualities where Douglas-fir has been planted during the last century.

\section{Conclusion}

Douglas-fir growth correlates with the climate, the soil moisture regime, and the soil nutrient status. The observed $\mathrm{pH}$ optimum between 4.5 and 7.2 corresponds to the broad physiological amplitude of Douglas-fir. Even though the nonnative tree species Douglas-fir is more drought resistant than our main native species, the expected temperature increase (e.g., higher summer temperatures) will also induce a decline in forest stand productivity for Douglas-fir. A lower productivity due to mean summer temperatures above $18{ }^{\circ} \mathrm{C}$ was observed at the warmest sites in Eastern Austria. Important macronutrients for Douglas-fir growth are phosphate, sulfate, and nitrogen; whereas high contents of the micronutrient iron reduce growth. The negative impact of clayey soils (clay content $>38 \%$ ) on Douglas-fir growth could be confirmed in our study, as they are often waterlogged. Despite the current recommendations in avoiding Douglas-fir plantation on calcareous soils, our study showed no significant differences in growth performance on carbonate and siliceous bedrock. However, it is important to note that our study covered only five out of 28 forest sites on rather loamy carbonate soils. We suggest that further Douglas-fir sites on carbonate soils need to be investigated.

Acknowledgements Open access funding provided by Austrian Science Fund (FWF).

Funding This work was supported by the Austrian Research Promotion Agency as part of the alpS project B04 AdaptAF B and CCDouglas II, and Austrian Science Fund (FWF) [Project ID: P26504]. We thank the Arenberg-Schleiden GmbH, Center Forst GmbH, Erzbischöfliches Forstamt Kirchberg, Esterhazy Betriebe GmbH, Forstamt Ottenstein, 
Forstamt Stift Göttweig, Forstverwaltung Grafenegg, Forstverwaltung Graf zu Toerring-Jettenbach, Fürstliche Forstverwaltung WaldburgWolfegg, Fürst Starhemberg'sche Familienstiftung, Fürst zu OettingenSpielberg'sche Forstverwaltung, Gräfliche Arco-Zinneberg'sche Domänenverwaltung, Grüne Lagune BIO-EN Energy Consulting GmbH, Gutsverwaltung Bubna-Litic, Habsburg-Lothringen'sches Gut Persenbeug, Hatschek Forste, Hoyos'sche Forstverwaltung Horn, Land and Forstbetriebe Niederösterreich, Landwirtschaftskammer Niederösterreich, Landwirtschaftskammer Österreich, LIECO GmbH \& Co KG, Montecuccoli Gut Mitterau, Österreichische Bundesforste AG, Thurn und Taxis Forste GmbH \& Co KG, Unternehmensgruppe Fürst von Hohenzollern-FORST, Waldgut Pleiderer GesmbH \& Co OG, and Wittgenstein-Berleburg'sche Rentkammer for financial support (listed in alphabetic order).

Data availability The dataset generated during and/or analyzed during the current study is available in the Figshare repository Eckhart et al. (2019) DF_site_growth_data. V1. FigShare. [Dataset]. https://doi.org/ 10.6084/m9.figshare.7553384.v1

\section{Compliance with ethical standards}

Conflicts of interest The authors declare that they have no conflict of interest.

Open Access This article is distributed under the terms of the Creative Commons Attribution 4.0 International License (http:// creativecommons.org/licenses/by/4.0/), which permits unrestricted use, distribution, and reproduction in any medium, provided you give appropriate credit to the original author(s) and the source, provide a link to the Creative Commons license, and indicate if changes were made.

Publisher's note Springer Nature remains neutral with regard to jurisdictional claims in published maps and institutional affiliations.

\section{References}

Aertsen W, Kint V, Van Orshoven J, Kürsad Ö, Muys B (2010) Comparison and ranking of different modelling techniques for prediction of site index in Mediterranean mountain forests. Ecol Model 221:1119-1130

Bastien J-C, Sanchez L, Michaud D (2013) Douglas-Fir (Pseudotsuga menziesii (Mirb.) Franco). In: Pâques L (ed) Forest tree breeding in Europe: current state-of-the-art. Springer Science+Business Media, Dordrecht, pp 325-373

Bergel D (1985) Douglasien-Ertragstafel für Nordwestdeutschland. Fachhochsch. Hildesheim/Holzminden, Fachber. Forstwirtsch., Göttingen

Bitterlich W (1948) Die Winkelzählprobe (The angle-count sample). Allgemeine Forst- und Holzwirtschaftszeitung 59:4-5

Blume H-P, Brümer GW, Horn R et al (2010) Scheffer/Schachtschabel: Lehrbuch der Bodenkunde. Spektrum Akademischer Verlag, Heidelberg

Bolte A, Ammer C, Löf M, Nabuurs G-J, Schall P, Spathelf P (2010) Adaptive forest management: a prerequisite for sustainable forestry in the face of climate change. In: Spathelf P (ed) Sustainable forest management in a changing world - a European perspective, Managing Forest Ecosystems 19:115-139, Springer, Dordrecht

Bontemps J-D, Bouriaud O (2014) Predictive approaches to forest site productivity: recent trends, challenges and future perspectives. Forestry 87(1):109-128
Boyle JR (1999) Introduction to planted forests: contributions to the quest for sustainable societies. In: Boyle JR, Winjum JK, Kavanagh K, Jensen EC (eds) Plantet forests: contributions to the quest for sustainable societies. Kluwer Academic Publishers, Dordrecht

Breiman L (2001) Random forests. Mach Learn 45:5-32

Carter RE, Klinka K (1990) Relationships between growing-season soil water-deficit, mineralizable soil nitrogen and site index of coastal Douglas fir. For Ecol Manag 30:301-311

Chakraborty D, Wang T, Andre K, Konnert M, Lexer MJ, Matulla C, Weißenbacher L, Schueler S (2016) Adapting Douglas-fir forestry in Central Europe: evaluation, application, and uncertainty analysis of a genetically based model. Eur J For Res 135:919-936

Clapp RB, Hornberger GM (1978) Empirical equations for some soil hydraulic properties. Water Resour Res 14:601-604

Cosby BJ, Hornberger GM, Clapp RB, Ginn TR (1984) A statistical exploration of the relationships of soil moisture characteristics to the physical properties of soils. Water Resour Res 20:682-690

Curt T, Bouchaud M, Agrech G (2001) Predicting site index of Douglasfir plantations from ecological variables in the Massif Central area of France. For Ecol Manag 149:61-74

Cutler DR, Edwards TC, Beard KH et al (2007) Random forests for classification in ecology. Ecology 88:2783-2792

Dormann CF, Elith J, Bacher S, Buchmann C, Carl G, Carré G, Marquéz JRG, Gruber B, Lafourcade B, Leitão PJ, Münkemüller T, McClean C, Osborne PE, Reineking B, Schröder B, Skidmore AK, Zurell D, Lautenbach S (2013) Collinearity: a review of methods to deal with it and a simulation study evaluating their performance. Ecography (Cop) 36:27-46

Eckenwalder JE (2009) Conifers of the world. Timber Press, Oregon

Eckhart T, Pötzelsberger E, Koeck R, Thom D, Lair GJ, van Loo M, Hasenauer H (2019) DF site growth data. V1. Figshare. [Dataset]. https://doi.org/10.6084/m9.figshare.7553384.v1

Englisch M (2008) Die Douglasie-Für und Wider aus standortskundlicher Sicht. In: Douglasie-Baumart mit Zukunft. BFW Praxisinformation 16:6-8, Bundesforschungss-und Ausbildungszentrum für Wald, Naturgefahren und Landschaft, Wien

Englisch M, Kilian W (eds) (1999) Anleitung zur Forstlichen Standortskartierung in Österreich (Guidelines for forest site mapping in Austria). FBVA Berichte 104, 2nd edn., Forstliche Bundesversuchsanstalt Wien, Waldforschungszentrum

Fageria NK (2014) Nitrogen management in crop production. CRC press, Boca Raton, Florida

Fontes L, Bontemps J-D, Bugmann H, Van Oijen M, Gracia C, Kramer K, Lindner M, Rötzer T, Skovsgaard J-P (2010) Models for supporting forest management in a changing environment. For Syst 19:8-29

Genuer R, Poggi J-M, Tuleau-Malot C (2015) VSURF: an R package for variable selection using random forests. R J 7(2):19-33

George E, Horst WJ, Neumann E (2012) Adaptation of plants to adverse chemical soil conditions. In: Marschner H (ed) Mineral nutrition of higher plants. 3rd edn. Academic Press, pp 409-472

Gould PJ, Harrington CA, Clair JBS (2012) Growth phenology of coast Douglas-fir seed sources planted in diverse environments. Tree Physiol 32:1482-1496

Hasenauer H, Merganicova K, Petritsch R, Pietsch SA, Thornton PE (2003) Validating daily climate interpolations over complex terrain in Austria. Agric For Meteorol 119:87-107

Hawkesford MJ, De Kok LJ (2006) Managing sulphur metabolism in plants. Plant Cell Environ 29:382-395

Hintsteiner WJ, van Loo M, Neophytou C, Schueler S, Hasenauer H (2018) The geographic origin of old Douglas-fir stands growing in Central Europe. In: Eur J For Res, vol 137, pp 447-461

IPCC (2014) Synthesebericht. Beitrag der Arbeitsgruppen I, II und II zum Fünften Sachstandsbericht des Zwischenstaatlichen Ausschusses für Klimaänderungen (IPCC) [Hauptautoren, R.K. Pachauri und L.A. Meyer (Hrsg.)]. Genf, Schweiz 
Jansen K, Sohrt J, Kohnle U, Ensminger I, Gessler A (2013) Tree ring isotopic composition, radial increment and height growth reveal provenance-specific reactions of Douglas-fir towards environmental parameters. Trees Struct Funct 27:37-52

Kindermann GE, Hasenauer H (2005) Zusammenstellung der Oberhöhenfunktionen für die wichtigsten Baumarten in Österreich. Aust J Forensic Sci 122:163-184

Kleinschmit J, Bastien J-C (1992) IUFRO's role in Douglas-fir (Pseudotsuga menziesii (Mirb.) Franco) tree improvement. Silvae Genet 41:161-173

Kleinschmit J, Svolta J, Weisgerber H et al (1979) Ergebnisse aus dem internationalen Douglasien-Herkunftsversuch von 1970 in der Bundesrepublik Deutschland. Silvae Genet 28:226-244

Kownatzki D, Kriebitzsch W-U, Bolte A, Liesebach H, Schmitt U, Elsasser P (2011) Zum Douglasienanbau in Deutschland (Growing Douglas fir in Germany). Johann Heinrich von Thünen-Institut, Special Issue 344

Lambers H, Chapin FS III, Thijs LP (1998) Plant physiological ecology. Springer, New York

Lambers H, Shane MW, Cramer MD et al (2006) Root structure and functioning for efficient acquisition of phosphorus: matching morphological and physiological traits. Ann Bot 98:693-713

Lavender DP, Hermann RK (2014) Douglas-fir: the genus Pseudotsuga. Forest research publications office, Oregon State University, Corvallis

Leitgeb E, Reiter R, Englisch M, et al (2012) Waldböden - Ein Bildatlas der wichtigsten Bodentypen, 1. Auflage. Wiley-VCH Verlag GmbH \& Co. KGaA

Liaw A, Wiener M (2015) Breiman and Cutler's random forests for classification and regression. Package random Forest version 4.5-16

LWF (2008) Die Douglasie - Perspektiven im Klimawandel. LWF Wissen 59, Bayerische Landesanstalt für Wald und Forstwirtschaft

Olden JD, Lawler JJ, Poff NL (2008) Machine learning methods without tears: a primer for ecologists. Q Rev Biol 83:171-193

Osman KT (2013) Forest soils: properties and management. Springer International Publishing, Cham

Petritsch R (2002) Anwendung und Validierung des Klimainterpolationsmodells DAYMET in Österreich (Application and validation of the climate interpolation model DAYMET in Austria). Master thesis, University of Natural Resources and Life Sciences, Vienna

Petritsch R, Hasenauer H (2014) Climate input parameters for real-time online risk assessment. Nat Hazards 70:1749-1762

Pollanschütz J (1971) Auswertung von Waldinventur (Analysis of forest inventory). In: 100 Jahre Hochschule für Bodenkultur, Fachveranstaltungen, Band IVTI.1. Grundlagen der Forst- und Holzwirtschaft, pp 355-369

Restaino CM, Peterson DL, Littell J (2016) Increased water deficit decreases Douglas fir growth throughout western US forests. Proc Natl Acad Sci 113:201602384

Rout GR, Sahoo S (2015) Role of iron in plant growth and metabolism. Rev Agric Sci 3:1-24

Rowell DL (1994) Bodenkunde: Untersuchungsmethoden und ihre Anwendungen, 1st edn. Springer Verlag, Berlin

Ruetz WF (1981) Douglasien-Herkunftsempfehlungen - ein Vorschlag für Bayern. In: Allgemeine Forstzeitschrift 36:1074-1077

Schmid M, Pautasso M, Holdenrieder O (2014) Ecological consequences of Douglas fir (Pseudotsuga menziesii) cultivation in Europe. Eur J For Res 133:13-29

Schultze U, Raschka H-D (2002) Douglasienherkünfte für den 'Sommerwarmen Osten' Österreichs: Ergebnisse aus DouglasienHerkunftsversuchen des Institutes für Forstgenetik. FBVA Berichte 126, Forstliche Bundesversuchsanstalt Wien

Spiecker H, Lindner M, Schuler J (eds) (2019) Douglas-fir - an option for Europe. EFI What science can tell us 9, European Forest Institute

Thornton PE, Hasenauer H, White M (2000) Simultaneous estimation of daily solar radiation and humidity from observed temperature and precipitation: an application over complex terrain in Austria. Agric For Meteorol 104:255-271

Weißenbacher L (2008) Herkunftswahl bei Douglasie - der Schlüssel für einen erfolgreichen Anbau. In: Douglasie-Baumart mit Zukunft. BFW Praxisinformation 16:3-5, Bundesforschungss-und Ausbildungszentrum für Wald, Naturgefahren und Landschaft, Wien 